\title{
Facile and efficient one-pot synthesis of benzimidazoles using lanthanum chloride
}

\author{
Yekkirala Venkateswarlu, Sudhagani Ramesh Kumar and Panuganti Leelavathi*
}

\begin{abstract}
Background: We report the synthesis of benzimidazoles using lanthanum chloride as an efficient catalyst. One-pot synthesis of 2-substituted benzimidazole derivatives from o-phenylenediamine and a variety of aldehydes were developed under mild reaction conditions.

Results: We have examined the effect of different solvents using the same reaction conditions. The yield of the product varied with the nature of the solvents, and better conversion and easy isolation of products were found with acetonitrile. In a similar manner, the reaction with o-phenylenediamine and 3,4,5-trimethoxybenzaldehyde was carried out without any solvents. The observation shows that the reaction was not brought into completion, even after starting for a period of $9 \mathrm{~h}$, and the reaction mixture showed a number of spots in thin-layer chromatography.

Conclusions: In conclusion, lanthanum chloride has been employed as a novel and efficient catalyst for the synthesis of benzimidazoles in good yields from o-phenylenediamine and a wide variety of aldehydes. All of the reactions were carried out in the presence of lanthanum chloride $(10 \mathrm{~mol} \%)$ in acetonitrile at room temperature.
\end{abstract}

Keywords: Benzimidazoles; Aldehydes; o-Phenylenediamine; Lanthanum chloride

\section{Background}

Benzimidazole nucleus is found in a variety of naturally occurring compounds such as vitamin B12 and its derivatives; it is structurally similar to purine bases. Benzimidazoles and its derivatives represent one of the most biologically active classes of compounds, possessing a wide spectrum of activities, and these are well documented in the literature. They show selective nonpeptide luteinizing hormone-releasing hormone antagonist, lymphocytespecific kinase inhibitor, $N$-methyl-D-aspartate antagonist, 5-liopoxygenase inhibitor, NS5B polymerase inhibitor (Figure 1), neuropeptide YY1 receptor antagonist, nonpeptide thrombin inhibitor, $\gamma$-aminobutyric acid receptor, factor Xa inhibitor, and poly (ADP-ribose) polymerase inhibitor. DNA-minor groove-binding agents possess antitumor activity, topoisomerase I inhibitors, angiotensin II inhibitors, and proliferation inhibitors. Several benzimidazole derivatives find applications that include antimicrobial, antihypertensive, anticancer antiulcer, antifungal, antihistamine activity, herbicides, and other veterinary applications as promising drugs in different therapeutic categories. The

*Correspondence: ameshteja_2001@yahoo.co.in

Department of Chemistry, Osmania University College for Women, Koti, Hyderabad 500095, India benzimidazole moieties express a significant activity against several viruses such as HIV, herpes (HSV-1), RNA influenza, human cytomegalovirus, selective angiotensin II inhibitors, and 5-HT3 antagonists. In addition, benzimidazoles are very impotent intermediates in synthetic routes and serve as ligands for asymmetric catalysts [1-8]. The high profile of biological applications of the benzimidazole compounds has prompted the emergence of extensive studies of their syntheses. In this context, numerous efforts have been made to synthesize benzimidazole derivatives. One of the most common methods for the preparation of benzimidazole derivatives involves the condensation of an $o$-phenylenediamine and carbonyl compounds such as aldehydes and acid derivatives. The condensation of $o$-phenylenediamine with carboxylic acid often requires strong acidic conditions and high temperatures $[9,10]$. The other method involves the oxidative cyclodehydrogenation of Schiff bases, which is generated from $o$-phenylenediamine and aldehydes in the presence of various catalysts.

This is the most popular approach in general for the synthesis of benzimidazole derivatives. The catalysts used are CAN, $\mathrm{K}_{3} \mathrm{PO}_{4}$, oxone, sulfamic acid, DDQ, PhI $(\mathrm{OAc})_{2}$, iodine, and $\mathrm{KHSO}_{4}$ [11-17]. In addition, several 
<smiles>CC(=O)c1ccc(-c2ccc(Cl)cc2)c(COc2ccc(-c3nc4cc(C(=O)O)ccc4n3C3CCCC3)cc2)c1</smiles>

NS5B RNA Polymerese inhibitor<smiles>COc1ccc2[nH]c(S(=O)Cc3ncc(C)c(OC)c3C)nc2c1</smiles>

$\mathrm{H}^{+} / \mathbf{k}^{+}$pump inhibitor

Figure 1 Scheme of NS5B polymerase and $\mathrm{H}^{+} / \mathrm{K}^{+}$inhibitors.

catalysts such as metal halides and metal oxychlorides, [18-22] metal oxides, PTSA, metal triflates, air, [23-30] ionic liquid, heteropoly acid, BDSB [31-33], proline, solid-supported catalysts, polymer-supported catalysts [34,35], and microwave-promoted [36-39] and clayzic [40] reactions have been reported in the literature. Unfortunately, many of these methods suffer from drawbacks such as drastic reaction conditions, low yields, tedious workup procedures, and co-occurrence of several side reactions. As a consequence, the introduction of an efficient and mild method is still needed to overcome these limitations.

As part of our research program in developing various synthetic methodologies [41-46], we report the synthesis of benzimidazoles using lanthanum chloride $\left(\mathrm{LaCl}_{3}\right)$ as an efficient catalyst. The catalyst is known as an efficient catalyst in the literature for various organic transformations [47-52].

\section{Methods}

Melting points were recorded on a Buchi R-535 apparatus (BUCHI Labortechnik AG, Flawi, Switzerland) and were uncorrected. Infrared (IR) spectra were recorded on a PerkinElmer FT-IR 240-c spectrophotometer (PerkinElmer Instruments, Branford, $\mathrm{CT}$, USA) using $\mathrm{KBr}$ discs. Hydrogen-1 nuclear magnetic resonance $\left({ }^{1} \mathrm{H}\right.$ NMR) spectra were recorded on a Gemini-200 spectrometer (Varian Medical Systems, Palo Alto, CA, USA) in $\mathrm{CDCl}_{3}$ using TMS as internal standard. Mass spectra were recorded on a Finnigan MAT 1020 (Thermo
Fisher Scientific, Waltham, MA, USA) mass spectrometer operating at $70 \mathrm{eV}$.

\section{Results and discussion}

In a typical experiment, a reaction was made to occur between 1,2-phenylenediamine (OPD) (1) and 3,4,5trimethoxybenzaldehyde (2) in the presence of $\mathrm{LaCl}_{3}$ in acetonitrile at room temperature to afford the corresponding product, 2-(3,4,5-trimethoxyphenyl)- $1 H$-benzo [d]imidazole (3), in excellent yield. The reaction was completed within $2 \mathrm{~h}$ (Scheme 1).

We have examined the effect of different solvents using the same reaction conditions, as shown in Table 1. The yield of the product varied with the nature of the solvents; better conversion and easy isolation of products were found with acetonitrile. Acetonitrile dissolves a wide range of ionic and nonpolar compounds. In a similar manner, the reaction with $o$-phenylenediamine and 3,4,5-trimethoxybenzaldehyde was carried out without any solvents. The observation shows that the reaction was not brought into completion, even after starting for a period of $9 \mathrm{~h}$, and the reaction mixture showed a number of spots in thin-layer chromatography (TLC).

In a similar manner, a comparative study on the role and requirement of the catalyst for condensation has been carried out, and the obtained results are clearly shown in Table 2. The reactants for this reaction are also $o$-phenylenediamine and 3,4,5-trimethoxybenzaldehyde in acetonitrile. From our observation, a catalytic amount

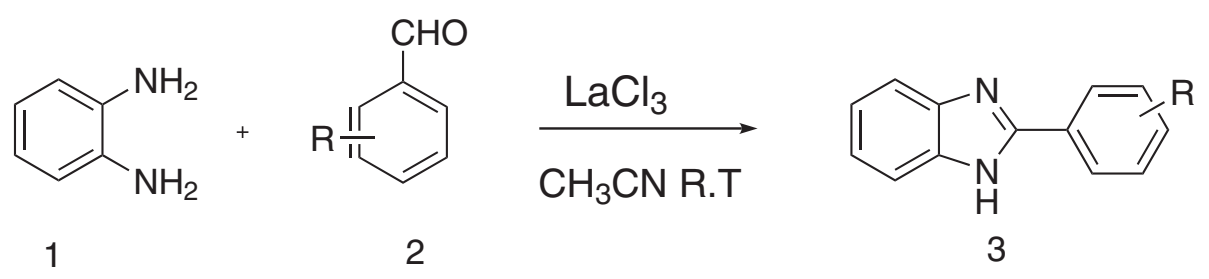

$\mathrm{R}=\mathrm{H}, \mathrm{Alkyl}, \mathrm{Aryl}$

Scheme 1 Reaction between 1,2-phenylenediamine (1) and 3,4,5-trimethoxybenzaldehyde (2) that yielded 2-(3,4,5-trimethoxyphenyl)-1Hbenzo[d]imidazole (3). 
Table 1 Comparative study of the solvent system

\begin{tabular}{llcc}
\hline Number & Solvent & Time (h) & Yield (\%) \\
\hline 1 & $\mathrm{CH}_{3} \mathrm{CN}$ & 2.0 & 95 \\
2 & $\mathrm{CH}_{3} \mathrm{OH}$ & 4.0 & 80 \\
3 & Dioxane & 5.0 & 75 \\
4 & THF & 6.0 & 70 \\
5 & Toluene & 7.0 & 65 \\
6 & DMF & 5.0 & 6 \\
7 & DCM & 8.0 & 50 \\
8 & - & 9.0 & - \\
\hline
\end{tabular}

(10 mol\%) of $\mathrm{LaCl}_{3}$ was enough to complete the conversion of aldehyde and $o$-phenylenediamine into the required condensation product.

A blank experiment was carried out with $o$-phenylenediamine and 3,4,5-trimethoxybenzaldehyde in the absence of the catalyst $\mathrm{LaCl}_{3}$, and the required 3,4,5trimethoxybenzimidazole product was not found even after stirring for $15 \mathrm{~h}$. Finally, it was decided that the suitable conditions for condensation is in a solvent and in the presence of an activator or promoter. As shown in Table 3, aromatic, heteroaromatic, $\alpha$-unsaturated and $\beta$-unsaturated aldehydes, and aliphatic aldehydes were reacted very well to afford the corresponding products of benzimidazole derivatives in very good to excellent yields. In general, the aromatic aldehydes having electron-donating groups and heteroaromatic compounds are reacting a little faster when compared with other aldehydes. In a similar manner, the aliphatic aldehydes and aromatic aldehydes containing electronwithdrawing groups are reacting comparatively a little slower in terms of conversion as well as yields, benzaldehyde and OPD, in the presence of the catalyst $\mathrm{Lacl}_{3}$. In general, all the reactions were completed within 2 to $4 \mathrm{~h}$, and the obtained yields were $85 \%$ to $95 \%$.

\section{Experimental}

\section{General procedure}

A mixture of $o$-phenylenediamine $(1.0 \mathrm{mmol})$ and aldehyde $(1.2 \mathrm{mmol})$ in the presence of lanthanum chloride

Table 2 Comparative study of catalyst

\begin{tabular}{lcc}
\hline Number & Amount of catalyst $\left(\mathbf{L a C l}_{\mathbf{3}}\right)(\mathbf{e q})$ & Time $(\mathbf{h})$ \\
\hline 1 & 0.1 & 2.0 \\
2 & 0.2 & 2.0 \\
3 & 0.4 & 3.5 \\
4 & 0.6 & 3.5 \\
5 & 0.8 & 3.0 \\
6 & 1.0 & 3.0 \\
7 & No catalyst & 15 \\
\hline
\end{tabular}

(10 mol\%) was stirred in acetonitrile $(5 \mathrm{ml})$ at room temperature. The progress of the reaction was monitored by TLC. After completion of the reaction as indicated by TLC, the solvent was removed under reduced pressure. The residue was dissolved in ethyl acetate and washed with water and brine. The organic layer was dried over $\mathrm{Na}_{2} \mathrm{SO}_{4}$ and concentrated under reduced pressure. The crude products were purified by column chromatography. All the products were identified by their ${ }^{1} \mathrm{H}$ NMR, IR, and mass spectroscopy data.

\section{Spectral data for selected compounds}

\section{2-(3,4,5-Trimethoxyphenyl)-1H-benzo[d]imidazole (3a)}

For this compound, the white solid's melting point was $259^{\circ} \mathrm{C}$. The IR $(\mathrm{KBr})$ frequency $(v)$ values were as follows: 2,924, 2,851, 1,601, 1,495, 1,463, 1,416, 1,282, 1,096, 1,020, 899, 801, 749, and $693 \mathrm{~cm}^{-1}$. The ${ }^{1} \mathrm{H}$ NMR $\left(\right.$ DMSO- $\mathrm{d}_{6}$ ) chemical shift $(\delta)$ values were as follows: $3.90(\mathrm{~s}, 3 \mathrm{H}), 4.00(\mathrm{~s}, 6 \mathrm{H}), 7.43$ to $7.60(\mathrm{~m}, 2 \mathrm{H}), 7.65(\mathrm{~s}$, $2 \mathrm{H})$, and 7.85 to $7.95(\mathrm{~m}, 2 \mathrm{H})$. The electron ionized mass spectrometry (EIMS) mass-to-ratio $(\mathrm{m} / \mathrm{z}$ ) values and corresponding percentage were as follows: $285\left(\mathrm{~m}^{+1} 100 \%\right)$, $269(10 \%), 255(10 \%)$, and $224(5 \%)$.

\section{4-(1H-Benzo[d]imidazol-2-yl)-N,N-dimethyl benzenamine}

(3b)

For this compound, the white solid's melting range was $288^{\circ} \mathrm{C}$ to $290^{\circ} \mathrm{C}$. The IR $(\mathrm{KBr}) v$ values were as follows: $2,853,2,800,1,740,1,611,1,561,15,276,1,446,1,389$, $1,362,1,324,1,278,1,230,1,200,1,167,1,106,1,064,948$, $819,800,744,769$, and $583 \mathrm{~cm}^{-1}$. The ${ }^{1} \mathrm{H}$ NMR $\left(\right.$ DMSO- $\left.\mathrm{d}_{6}\right) \delta$ values were as follows: $2.90(\mathrm{~s}, 6 \mathrm{H}), 6.70$ (dd, 2H), $6.95(\mathrm{~d}, 2 \mathrm{H}), 7.10$ to $7.25(\mathrm{~m}, 2 \mathrm{H})$, and 7.60 (dd, $2 \mathrm{H}$ ). The EIMS $\mathrm{m} / \mathrm{z}$ values and percentage were as follows: $238\left(\mathrm{~m}^{+1} 100 \%\right), 157(30 \%), 134(80 \%)$, and $109(10 \%)$.

\section{2-(4-(Allyoxy)-3-methoxyphenyl)-1H-benzo[d]imidazole (3c)}

For this compound, the solid's IR ( $\mathrm{KBr}) v$ values were as follows: 3,063, 2,923, 2,853, 1,886, 1,747, 1,649, 1,607, $1,580,1,449,1,460,1,422,1,387,1,316,1,250,1,215$, 1,180, 1,138, 1,027, 991, 924, 866, 805, 763, 743, 628, and $594 \mathrm{~cm}^{-1}$. The ${ }^{1} \mathrm{H}$ NMR (DMSO- $\left.\mathrm{d}_{6}\right) \delta$ values were as follows: $3.75(\mathrm{~s}, 3 \mathrm{H}), 4.55(\mathrm{~d}, 2 \mathrm{H}), 5.25(\mathrm{~d}, 1 \mathrm{H}), 5.40$ $(\mathrm{t}, 2 \mathrm{H}), 5.95$ to $6.10(\mathrm{~m}, 1 \mathrm{H}), 6.60(\mathrm{~d}, 1 \mathrm{H}) 6.73(\mathrm{t}, 1 \mathrm{H})$, 7.15 to $7.35(\mathrm{~m}, 2 \mathrm{H}), 7.50$ to $7.60(\mathrm{~m}, 2 \mathrm{H})$, and 7.80 $(\mathrm{d}, 2 \mathrm{H})$. The EIMS $\mathrm{m} / \mathrm{z}$ values and corresponding percentage were as follows: $280\left(\mathrm{~m}^{+1} 100 \%\right)$ and 242 (80\%).

\section{2-(Furan-2-yl)-1H-benzo[d]imidazole (3d)}

For this compound, the solid's melting point was $296^{\circ} \mathrm{C}$. The IR $(\mathrm{KBr}) v$ values were as follows: 2,927, 2,857, $1,741,1,609,1,545,1,462,1,379,1,189,1,069,751$, and 
Table 3 Lanthanum chloride-catalyzed synthesis of benzimidazoles

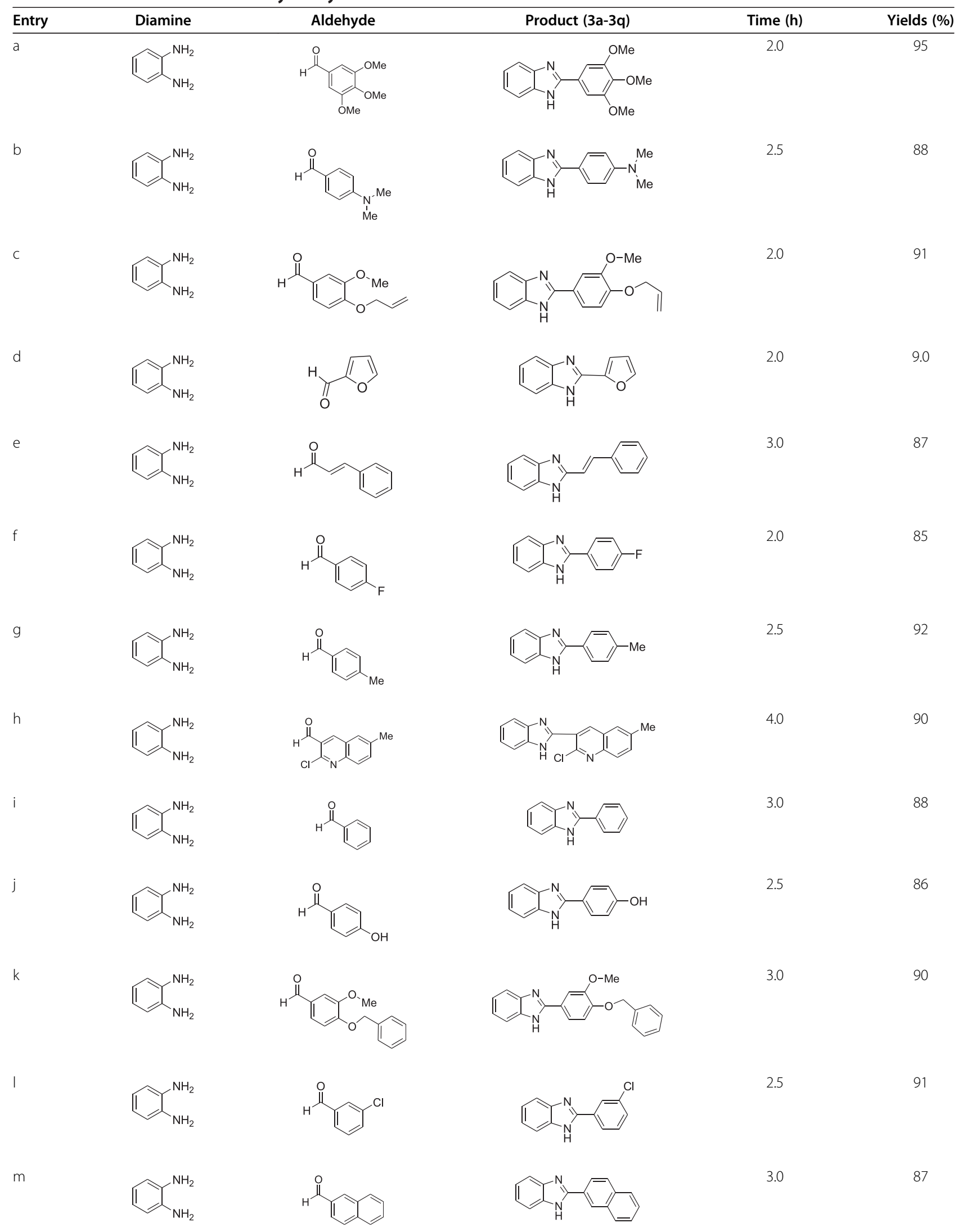


Table 3 Lanthanum chloride-catalyzed synthesis of benzimidazoles (Continued)

(n)

$597 \mathrm{~cm}^{-1}$. The ${ }^{1} \mathrm{H}$ NMR (DMSO- $\left.\mathrm{d}_{6}\right) \delta$ values were as follows: $6.30(\mathrm{~d}, 2 \mathrm{H}), 7.15$ to $7.35(\mathrm{~m}, 2 \mathrm{H}), 7.40(\mathrm{~d}, 1 \mathrm{H})$, and $7.65(\mathrm{~d}, 2 \mathrm{H})$. The EIMS $m / z$ values and corresponding percentage were as follows: $184\left(\mathrm{~m}^{+1} 100 \%\right), 158$ (20\%), 137 (5\%), and 133 (5\%).

\section{(E)-2-Styryl-1H-benzo[d]imidazole (3e)}

For this compound, the solid's melting range was $201^{\circ} \mathrm{C}$ to $203^{\circ} \mathrm{C}$. The IR $(\mathrm{KBr}) v$ values were as follows: 3,377 , $3,027,2,924,2,853,1,948,1,805,1,633,1,598,1,495$, $1,449,1,402,1,355,1,326,1,284,1,194,1,153,1,070$, 1,018, 963, 918, 841, 737, 691, and $558 \mathrm{~cm}^{-1}$. The ${ }^{1} \mathrm{H}$ NMR (DMSO- $\mathrm{d}_{6}$ ) $\delta$ values were as follows: 6.40 (dd, $1 \mathrm{H}), 6.55(\mathrm{~d}, 1 \mathrm{H}), 7.15$ to $7.55(\mathrm{~m}, 7 \mathrm{H})$, and $7.70(\mathrm{~d}, 2 \mathrm{H})$. The EIMS $\mathrm{m} / \mathrm{z}$ values and corresponding percentage were as follows: $220\left(\mathrm{~m}^{+1} 15 \%\right), 195$ (5\%), 174 (5\%), 155 (5\%), 144 (5\%), and 134 (5\%).

\section{2-(4-Fluorophenyl)-1H-benzo[d]diazole (3f)}

For this compound, the white solid's melting point was $248^{\circ} \mathrm{C}$. The IR $(\mathrm{KBr}) v$ values were as follows: 3,053, $2,930,1,663,1,624,1,545,1,486,1,440,1,315,1,277$, 1,229, 1,094, 1,034, 1,004, 972, 833, 795, 746, 690, 618, and $568 \mathrm{~cm}^{-1}$. The ${ }^{1} \mathrm{H}$ NMR (DMSO- $\left.\mathrm{d}_{6}\right) \delta$ values were as follows: 7.15 to $7.20(\mathrm{~m}, 2 \mathrm{H}), 7.20$ to $7.40(\mathrm{~m}, 2 \mathrm{H})$, 7.45 to $7.52(\mathrm{~m}, 2 \mathrm{H}), 7.60$ to $7.70(\mathrm{~m}, 2 \mathrm{H})$, and 8.00 (brs, $1 \mathrm{H})$. The EIMS $\mathrm{m} / z$ values and corresponding percentage were as follows: $212\left(\mathrm{~m}^{+} 100 \%\right), 193(5 \%), 215$ (15\%), 168 (5\%), 155 (5\%), 136 (5\%), 129 (5\%), and 95 (5\%).

\section{2-p-Tolyl-1H-benzo[d]imidazole (3g)}

For this compound, the white solid's melting point was $275^{\circ} \mathrm{C}$. The IR $(\mathrm{KBr}) v$ values were as follows: 3,397, $3,027,2,922,2,858,1,813,1,514,1,481,1,452,1,412$, 1,383, 1,348, 1,282, 1,250, 1,183, 1,157, 1,114, 1,021, 987, 823, 746, and 612.cm ${ }^{-1}$. The ${ }^{1} \mathrm{H}$ NMR (DMSO- $\mathrm{d}_{6}$ ) $\delta$ values were as follows: $2.35(\mathrm{~s}, 3 \mathrm{H}), 4.42$ (brs, $1 \mathrm{NH})$, 6.95 (d, 2H), 7.10 (d, 2H), 7.28 (d, 2H), and 7.55 (d, 2H). The EIMS $\mathrm{m} / \mathrm{z}$ values and corresponding percentage were as follows: $208\left(\mathrm{~m}^{+}\right.$100\%), 195 (15\%), 179 (20\%), 161 (10\%), 153 (10\%), 149 (5\%), 140 (20\%), 136 (5\%), 126 (10\%), and $122(5 \%)$.

\section{3-(1H-Benzo[d]imidazol-2-yl)-2-chloro-6-methylquinoline (3h)}

For this compound, the solid's IR ( $\mathrm{KBr}) v$ values were as follows: $3,073,1,585,1,493,1,435,1,392,1,331,1,280$, 1,227, 1,147, 1,031, 929, 816, 748, 711, 646, 579, and 483 $\mathrm{cm}^{-1}$. The ${ }^{1} \mathrm{H}$ NMR (DMSO- $\mathrm{d}_{6}$ ) $\delta$ values were as follows: $2.60(\mathrm{~s}, 3 \mathrm{H}), 7.25(\mathrm{~d}, 2 \mathrm{H}), 7.70(\mathrm{~d}, 1 \mathrm{H}), 7.80(\mathrm{~d}$, $2 \mathrm{H}), 7.90(\mathrm{~d}, 2 \mathrm{H})$, and $8.80(\mathrm{~s} 1 \mathrm{H})$. The EIMS $\mathrm{m} / z$ values and corresponding percentage were as follows: $294\left(\mathrm{~m}^{+}\right.$ 70\%), 290 (10\%), 274 (40\%), 258 (5\%), 246 (5\%), 230 (5\%), 212 (5\%), 191 (10\%), and 169 (5\%).

\section{2-Phenyl-1H-benzo[d]imidazole (3i)}

For this compound, the white powder's melting point was $295^{\circ} \mathrm{C}$. The IR (KBr) $v$ values were as follows: 3,406, 3,047, 1,589, 1,540, 1,443, 1,409, 1,483, 1,275, 1,118, 736, and $704 \mathrm{~cm}^{-1}$. The ${ }^{1} \mathrm{H}$ NMR (DMSO- $\left.\mathrm{d}_{6}\right) \delta$ values were 4.50 (brs, $1 \mathrm{H}), 7.20$ to $7.40(\mathrm{~m}, 2 \mathrm{H}), 7.50$ to $7.75(\mathrm{~m}$, $5 \mathrm{H}), 7.70(\mathrm{~d}, 2 \mathrm{H})$, and $8.25(\mathrm{~d}, 2 \mathrm{H})$. EIMS $\mathrm{m} / \mathrm{z}$ values and corresponding percentage were as follows: 195 $\left(\mathrm{m}^{+} 10 \%\right), 175(5 \%)$, and $160(5 \%)$.

\section{4-(1H-Benzo[d]imidazole-2yl) phenol (3j)}

For this compound, the white powder's melting range was $229^{\circ} \mathrm{C}$ to $230^{\circ} \mathrm{C}$. The IR ( $\left.\mathrm{KBr}\right) v$ values were as follows: 3,376, 3,290, 3,027, 2,807, 1,697, 1,611, 1,591, $1,515,1,443,1,394,1,268,1,246,839$, and $745 \mathrm{~cm}^{-1}$. The ${ }^{1} \mathrm{H}$ NMR (DMSO- $\mathrm{d}_{6}$ ) $\delta$ values were as follows: $6.90(\mathrm{~d}$, $1 \mathrm{H}), 7.05$ to $7.15(\mathrm{~m}, 4 \mathrm{H})$, and $7.75(\mathrm{~d}, 2 \mathrm{H})$. The EIMS 
$\mathrm{m} / \mathrm{z}$ values and corresponding percentage were as follows: $210\left(\mathrm{~m}^{+} 100 \%\right), 193$ (5\%), 191 (20\%), 183 (10\%), 181 (5\%), 169 (40\%), 154 (5\%), 137 (5\%).

\section{2-(4-(Benzyloxy)-3-methoxyphenyl)-1H-benzo[d]imidazole (3k)}

For this compound, the IR $(\mathrm{KBr}) v$ values were as follows: 3,036, 2,924, 2,853, 1,738, 1,604, 1,497, 1,458, 1,384, 1,321, 1,240, 1,209, 1,175, 1,132, 1,028, 992, 905, 802, 740, 697, 641, and 572, and $465 \mathrm{~cm}^{-1}$. The ${ }^{1} \mathrm{H}$ NMR (DMSO- $\left.\mathrm{d}_{6}\right) \delta$ values were as follows: $3.73(\mathrm{~s}, 3 \mathrm{H})$, $5.15(\mathrm{~s}, 2 \mathrm{H}), 6.55(\mathrm{~d}, 1 \mathrm{H}), 6.55(\mathrm{~d}, 1 \mathrm{H}), 6.75(\mathrm{dd}, 2 \mathrm{H})$ 7.10 to $7.50(\mathrm{~m}, 7 \mathrm{H})$, and $7.80(\mathrm{~d}, 2 \mathrm{H})$. The EIMS $\mathrm{m} / \mathrm{z}$ (first set) values and corresponding percentage were as follows: $330\left(\mathrm{~m}^{+} 60 \%\right), 313$ (10\%), 305 (20\%), 289 (5\%), 261 (30\%), 245 (20\%), 227 (100\%), 210 (20\%), 201 (50\%), 195 (20\%), 157 (20\%), 100 (30\%), 91 (10\%), and 89 (5\%). The EIMS $\mathrm{m} / \mathrm{z}$ (second set) values and corresponding percentage were as follows: $245\left(\mathrm{~m}^{+} 100 \%\right), 243$ (5\%), and $141(10 \%)$. The EIMS $m / z$ (third set) values and corresponding percentage were as follows: $245\left(\mathrm{~m}^{+} 100 \%\right)$, 243 (5\%), and 141 (10\%).

\section{2-(3-Chlorophenyl)-1H-benzo[d]imidazole (31)}

For this compound, the white powder's melting range was $232^{\circ} \mathrm{C}$ to $234^{\circ} \mathrm{C}$. The IR ( $\left.\mathrm{KBr}\right) v$ values were as follows: $3,059,1,619,1,593,1,440,1,421,1,269,836$, and $750 \mathrm{~cm}^{-1}$. The ${ }^{1} \mathrm{H}$ NMR (DMSO-d6 MHz) $\delta$ values were as follows: 7.45 to $7.60(\mathrm{~m}, 4 \mathrm{H}), 7.62$ to $7.72(\mathrm{~m}, 2 \mathrm{H})$, and 8.30 to $8.45(\mathrm{~m}, 2 \mathrm{H})$. The EIMS $m / z$ value with its corresponding percentage was $229\left(\mathrm{~m}^{+} 100 \%\right)$.

\section{2-(Naphthalene-2yl)-1H-benzo[d]imidazole (3m)}

For this compound, the white powder's melting range was $218^{\circ} \mathrm{C}$ to $219^{\circ} \mathrm{C}$. The IR ( $\left.\mathrm{KBr}\right) v$ values were as follows: 3,425, 3,047, 2,924, 2,853, 1,624, 1,605, 1,447, 1,385, and $748 \mathrm{~cm}^{-1}$. The ${ }^{1} \mathrm{H}$ NMR (DMSO-d6) $\delta$ values were as follows: 6.70 to $6.90(\mathrm{~m}, 2 \mathrm{H}), 7.20$ to $7.35(\mathrm{~m}, 2 \mathrm{H})$, 7.55 to $7.80(\mathrm{~m} 4 \mathrm{H})$, and 7.90 to $8.10(\mathrm{~m}, 2 \mathrm{H})$. The EIMS $\mathrm{m} / \mathrm{z}$ values and corresponding percentage were as follows: $245\left(\mathrm{~m}^{+} 100 \%\right), 243(5 \%)$, and 141 (10\%).

\section{(E)-2-(Pent-en-2-yl)-1H-benzo[d]imidazole (3n)}

For this compound, the IR $(\mathrm{KBr}) v$ values were as follows: 3,064, 2,963, 2,923, and 1,648 $\mathrm{cm}^{-1}$. The ${ }^{1} \mathrm{H}$ NMR (DMSO-d6) $\delta$ values were as follows: $1.10(\mathrm{t}, 3 \mathrm{H}), 1.80$ $(\mathrm{m}, 2 \mathrm{H}), 1.95$ to $2.10(\mathrm{~m}, 2 \mathrm{H}), 5.90(\mathrm{dd}, 1 \mathrm{H}), 7.30$ (d, $2 \mathrm{H})$, and $7.75(\mathrm{~d}, 2 \mathrm{H})$. The EIMS $m / z$ value was 187 .

\section{2-(4-Nitrophenyl)-1H-benzo[d]imidazole (3o)}

For this compound, the yellow powder's melting point was $314^{\circ} \mathrm{C}$. The IR $(\mathrm{KBr}) v$ values were $3,042,1,604$, $1,515,1,434,1,353,854,745$, and $710 \mathrm{~cm}^{-1}$. The ${ }^{1} \mathrm{H}$ NMR (DMSO-d6) $\delta$ values were as follows: 7.10 to 7.15 (m, 2H), $7.30(\mathrm{~d}, 1 \mathrm{H}), 7.35(\mathrm{~d}, 1 \mathrm{H}), 7.40(\mathrm{t}, 1 \mathrm{H}), 7.45(\mathrm{t}$, $1 \mathrm{H}), 8.0(\mathrm{dd}, 2 \mathrm{H})$, and 13.0 (brs, $1 \mathrm{H})$. The EIMS $\mathrm{m} / \mathrm{z}$ values and corresponding percentage were as follows: $240\left(\mathrm{~m}^{+} 100 \%\right), 226$ (5\%), 211 (10\%), 194 (20\%), and $182(5 \%)$.

\section{2-(Pyridine-2-yl)-1H-benzo[d]imidazole (3p)}

For this compound, the solid's melting range was $245^{\circ} \mathrm{C}$ to $248^{\circ} \mathrm{C}$. The IR $(\mathrm{KBr}) v$ values were as follows: 3,068 , $1,449,1,402,1,280$, and $746 \mathrm{~cm}^{-1}$. The ${ }^{1} \mathrm{H}$ NMR (DMSO-d6) $\delta$ values were as follows: $6.85(\mathrm{~m}, 2 \mathrm{H})$, 7.00 to $7.10(\mathrm{~m}, 1 \mathrm{H}), 7.45$ to $7.55(\mathrm{~m}, 1 \mathrm{H}), 7.80$ to 7.90 $(\mathrm{m}, 2 \mathrm{H}), 8.10(\mathrm{t}, 1 \mathrm{H})$, and $8.65(\mathrm{~d}, 1 \mathrm{H})$. EIMS $m / z$ value with its corresponding percentage was $196\left(\mathrm{~m}^{+} 15 \%\right)$.

\section{4-(1H-Benzo[d]imidazole-2yl) benzonitrile (3q)}

For this compound, the white crystal solid's melting point was $262^{\circ} \mathrm{C}$. The IR ( $\left.\mathrm{KBr}\right) v$ values were as follows: $3,417,3,047,2,912,2,222,1,605,1,454,1,408$, and $748 \mathrm{~cm}^{-1}$. The ${ }^{1} \mathrm{H}$ NMR (DMSO-d6) $\delta$ values were as follows: 5.50 (brs, $1 \mathrm{H}), 7.45$ to 7.60 (m, 2H), 7.82 to 7.90 (m, 2H), 8.05 $(\mathrm{d}, 2 \mathrm{H})$, and $8.50(\mathrm{~d}, 2 \mathrm{H})$. The EIMS $m / z$ values and corresponding percentage were as follows: $220\left(\mathrm{~m}^{+} 100 \%\right), 211$ (10\%), 196 (5\%), and 186 (5\%).

\section{Conclusions}

In conclusion, lanthanum chloride has been employed as a novel and efficient catalyst for the synthesis of benzimidazoles in good yields from $o$-phenylenediamine and a wide variety of aldehydes. All the reactions were carried out at room temperature while using the catalyst lanthanum chloride in $10 \mathrm{~mol} \%$. The reaction conditions were very mild, and the isolation of products was also very easy.

\section{Competing interests}

The authors declare that they have no competing interests.

\section{Authors' information}

$\mathrm{W}$ and SRK are research scholars, and PL is a professor at the Department of Chemistry, University College for Women, Koti Osmania University, Hyderabad 500095, India.

\section{Acknowledgments}

The authors are thankful to the director of IICT for providing the working space and chemicals.

\section{Received: 7 February 2012 Accepted: 15 March 2013}

Published: 6 August 2013

\section{References}

1. Nakano H, Inoue T, Kawasaki N, Miyataka H, Matsumoto H, Taguchi T, Inagaki N, Nagai H, Satoh T (2000) Synthesis of biologically activities of novel anti-allergic agents with 5-lipoxygenase inhibiting action. Bioorg Med Chem 8:373-380

2. Hauel HN, Nar H, Priepke H, Ries U, Stassen J, Wienen W (2002) Structurebased design of novel potent nonpeptide thrombin inhibitors. J Med Chem 45:1757-1766 
3. He Y, Wu B, Yang J, Robinson D, Risen L, Ranken R, Blyn L, Sheng S, Swayze EE (2003) 2-Piperidin-4-yl-benzimidazoles with broad spectrum antibacterial activities. Bioorg Med Chem Lett 13:3253-3256

4. Porcari RA, Devivar RV, Kucera LS, Cdreach J, Townsend BL (1998) Design, synthesis and antiviral evaluations of 1-(substituted benzyl)-2-substituted-5, 6-dichlorobenzimidazoles as non nucleoside analogues of 2,5,6-trichloro-1( $\beta$-D-ribofuranosyl) benzimidazole. J Med Chem 41:1252-1262

5. Roth T, Morningstar LM, Boyer LP, Hughes MS, Buckheitjr RW, Michejda JC (1997) Synthesis and biological activity of novel nonnucleoside inhibitors of HIV-1 reverse transcriptase. 2-Aryl-substituted benzimidazoles. J Med Chem 40:4199-4207

6. Migawa TM, Girardet $\sqcup$, Walker AJ, Koszalka WG, Chamberjain DS, Drach C, Townsend BL (1998) Design, synthesis, and antiviral activity of a-nucleosides: D-and L-isomers of lyxofuranosyl and (5-deoxylyxofuranosyl) benzimidazoles. J Med Chem 41:1242-1251

7. Mann J, Baron AY, Opoku-Boahen Y, Johansoon E, Parkmson G, Kelland RL, Neidle $S$ (2001) A new class of symmetric bisbenzimidazole based DNA minor groove-binding agents showing antitumor activity. J Med Chem 44:138-144

8. Figge A, Altenbach JH, Brauer DJ, Tielmann P (2002) Synthesis and resolution of 2-(2-diphenylphosphinyl-naphthalen-1-yl)-1-isopropyl-1Hbenzimidazole: a new atropisomeric $\mathrm{P}, \mathrm{N}$-chelating ligand for asymmetric catalysis. Tetrahedron-Asymmetry 13:137-144

9. Hisano T, Ichikawa M, Tsumoto K, Tasaki M (1982) Synthesis of benzoxazoles, benzothiazoles and benzimidazoles and evaluation of their antifungal, insecticidal and herbicidal activities. Chem Pharm Bull 30:2996-3004

10. Kumar BVS, Vaidya SD, Kumar RV, Bhirud SB, Mane RB (2006) Synthesis and anti-bacterial activity of some novel 2-(6-fluorochroman-2-yl)-1-alkyl/acyl/ aroyl-1H-benzimidazoles. Eur J Med Chem 41:599-604

11. Bahrami K, Khodaei MM, Naali F (2008) Mild and highly efficient method for the synthesis of 2-arylbenzimidazoles and 2-arylbenzothiazoles. J Org Chem 73:6835-6837

12. Buchwald SL, Zheng N, Anderson KW, Huang X, Nguyen HN (2007) A palladium-catalyzed regiospecific synthesis of $\mathrm{N}$-arylbenzimidazoles. Angew Chem 46:7509-7512

13. Beaulieu PL, Hache B, Moon VE (2003) A practical oxone-mediated, highthrough, solution-phase synthesis of benzimidazoles from 1,2phenylenediamines and aldehydes and its application to preparative-scale synthesis. Synthesis 11:1683-1692

14. Eynde JJV, Delfosse F, Lor P, Van YH (1995) 2,3-Dichloro-5, 6-dicyano-1,4benzoquinone, a mild catalyst for the formation of $\mathrm{C}-\mathrm{N}$ bonds. Tetrahedron 51:5813-5818

15. Du LH, Wang YG (2007) A rapid and efficient synthesis of benzimidazoles using hypervalent iodine as oxidant. Synthesis 5:675-678

16. Du HL, Luo AP (2010) Efficient and one-pot synthesis of and benzimidazoles under solvent free conditions. Synth Commun 40:2880-2886

17. Gogoi P, Konwar D (2006) An efficient and one-pot synthesis of imidazolines and benzimidazoles via anaerobic oxidation of $\mathrm{C}-\mathrm{N}$ bonds in water. Tetrahedron Lett 47:79-82

18. Singh PM, Sasmal S, Lu W, Chatterjee NM (2000) Synthetic utility of catalytic $\mathrm{Fe}(\mathrm{III}) / \mathrm{Fe}(\mathrm{II})$ redox cycling towards fused heterocycles: a facile access to substituted benzimidazoles, bisbenzimidazoles and imidazopyridine derivatives. Synthesis 10:1380-1390

19. Wang XJ, Zhang L, Xu Y, Murthy DK, Senanayake CS (2004) A practical synthesis of 2-(N-substituted)-amino-benzimidazoles utilizing $\mathrm{CuCl}$ promoted intramolecular cyclization of $\mathrm{N}$-(2-aminoaryl)thioureas. Tetrahedron Lett 45:7167-7170

20. Alloum AB, Bougrin K, Soufiaoui M (2003) Synthese chimioselective des benzimidazoles sursilice traitee parlechlorure du thionyle. Tetrahedron Lett 44:5935-5937

21. Yang D, Fu H, Hu L, Jiang Y, Zhao Y (2008) Copper-catalyzed synthesis of benzimidazoles via cascade reactions of o-halo acetanilide derivatives with amidine hydrochlorides. J Org Chem 73:7841-7844

22. Subramanyam SC, Narayanan S (2010) Yttrium (III) chloride: a mild and efficient catalyst for the synthesis of benzimidazoles. Int J Apples Bio and Phar Tech 1:689-694

23. Tandon VK, Kumar M (2004) $\mathrm{BF}_{3}-\mathrm{Et}_{2} \mathrm{O}$-promoted one-pot expeditious and convenient synthesis of 2-substituted benzimidazoles and 3,1, 5-benzoxadiazepines. Tetrahedron Lett 45:4185-4187

24. Shinde $\mathrm{B}$, Nagawade $\mathrm{RR}$ (2006) $\mathrm{BF}_{3}-\mathrm{Et}_{2} \mathrm{O}$ promoted solvent free synthesis of benzimidazole derivatives. Chin Chem Lett 17:453-456
25. Yulu W, Huiqiang M, Xiangming $\mathrm{H}$ (2007) p-TsOH catalyzed synthesis of 2arylsubstituted benzimidazoles. ARKIVOC 2007(13):150-154

26. Trivedi R, De SK, Gibbs RA (2006) A convenient one-pot synthesis of 2 substituted benzimidazoles. J Mol Catal A 245:8-11

27. Currini M, Epifano F, Motanari F, Rosati O, Taccone S (2004) Yttrium triflate promoted synthesis of benzimidazole derivatives. Synlett 10:1832-1834

28. Chari MA, Sadanandam P, Shobha D, Mukkanti K (2010) A Simple mild, and efficient procedure for benzimidazoles using copper triflate as catalyst. Heterocyclic Chem 47:153-155

29. Reddy AR, Narasaiah AV, Yadav JS (2011) Mild and efficient protocol for the synthesis of benzimidazoles using samarium triflate. Synth Commun 41:262-267

30. Lin S, Yang L (2005) A simple and efficient procedure for the synthesis of benzimidazoles using air as the oxidant. Tetrahedron Lett 46:4315-4319

31. Nadaf RN, Siddiqui SA, Daniel T, Lahoti RJ, Srinivasan KV (2004) Roomtemperature ionic liquid-promoted region selective synthesis of 2-aryl benzimidazoles, benzoxazoles and benzthiazoles under ambient conditions. J Mol Catal A 214:155-160

32. Heravi MM, Sadjadi S, Oskooie HA, Shoar RH, Bamoharram FF (2008) Heteropoly acids as heterogeneous and recyclable catalysts for the synthesis of benzimidazoles. Catal Commun 8:504-507

33. Das B, Holla H, Srinivas Y (2007) Efficient (bromodimethysulfonium bromide mediated synthesis of benzimidazoles. Tetrahedron Lett 48:61-64

34. Zou B, Yuan Q, Ma D (2007) Synthesis of 1,2-disubstituted benzimidazoles by a Cu-catalyzed cascade aryl amination/condensation process. Angew Chem 46:2598-2601

35. Varala R, Nasreen A, Enugala R, Adapa SR (2007) L-Proline catalyzed selective synthesis of 2-aryl-1-arylmethyl-1 $\mathrm{H}$-benzimidazoles. Tetrahedron Lett 48:69-72

36. Wu CH, Sun CM (2006) Parallel synthesis of amino bis-benzimidazoles by multistep microwave irradiation. Tetrahedron Lett 47:2601-2604

37. Surpur MP, Singh PR, Patil SB, Samant SD (2007) One-pot synthesis of benzimidazoles from o-nitro anilines under microwaves via a reductive cyclization. Synth Commun 37:1375-1379

38. Wang Y, Sarris K, Sauer DR, Djuric SW (2006) A simple and efficient one step synthesis of benzoxazoles and benzimidazoles from carboxs. Tetrahedron Lett 47:4823-4826

39. Mao Z, Wang Z, Li J, Song X, Luo Y (2010) Rapid and cheap synthesis of benzimidazoles via intermittent microwave promotion: a simple and potential industrial application of air as oxidant. Synth Commun 40:1963-1977

40. Pitchumani K, Kanagaraj K, Dhakshinamoorthy A (2011) A $\mathrm{Zn}^{2+}$ K10-clay (clayzic) as an efficient water-tolerant, solid acid catalyst for the synthesis of benzimidazoles and quinoxalines at room temperature. Tetrahedron Lett 52:69-73

41. Kumar SR, Venkateswarlu Y, Leelavathi P (2011) Synthesis of 1, 5-benzodiazepines catalysed by $\mathrm{Zn}(\mathrm{OTf})_{2}$ in solvent free medium. Asian J Chem 23:1611-1614

42. Venkateswarlu $Y$, Leelavathi $P(2010) \mathrm{NbCl}_{5}$ : an efficient catalyst for the synthesis of quinoxalines. Lett Org Chem 7:208-211

43. Venkateswarlu $Y$, Kumar SR, Leelavathi $P$ (2012) $\mathrm{CdCl}_{2}$ : a simple and efficient catalyst for the synthesis of 1,4-dihydropyridine. (Hantzsch pyridines). Int J Ind Chem 3:18

44. Venkateswarlu Y, Kumar SR, Leelavathi P (2011) Eu(OTf) $)_{3}$ : an efficient catalyst for one-pot synthesis of 3,4-dihydropyrimidin-2(1H)-ones. Organic Synthesis and Medicinal Chemistry ASAP

45. Venkateswarlu Y, Kumar SR, Leelavathi P (2012) A simple and efficient protocol for the synthesis of quinolines catalyzed by chloramines-T. Org Commun 5(3):120

46. Kumar SR, Venkateswarlu Y, Leelavathi $P(2012) \mathrm{LaCl}_{3}$ : an efficient catalyst for the synthesis of substituted thiazoles. Organic synthesis and medicinal chemistry 1:11-14

47. Narsaiah AV (2007) Lanthanum trichloride $\left(\mathrm{LaCl}_{3}\right)$ : accelerated conjugate addition of amines to electron-poor alkenes. Lett Org Chem 4(7):462-464

48. Luche JL, Gemal AL (1978) Efficient synthesis of acetals catalyzed by rare earth chlorides. Chem Commun 1978:976-977

49. Narsaiah AV, Nagaiah K (2003) $\mathrm{LaCl}_{3}$ : mediated regeneration of carbonyl compounds from oximes in water. Ind J Chem 42(9):2045-2047 
50. Narsaiah AV, Nagaiah K (2003) An efficient Knoevenagel condensation catalyzed by $\mathrm{LaCl}_{3}$ in heterogeneous medium. Synth Commun 33:3825-3832

51. Narsaiah AV (2007) LaCl 3 : an efficient catalyst for the silylation of hydroxyl groups by activating HMDS. J Orgnomet Chem 692:3614

52. Lu J, Bai Y, Wang Z, Yang B, Ma H (2000) One-pot synthesis of 3,

4-dihydropyrimidin-2(1H)-ones using $\mathrm{LaCl}_{3}$ as a catalyst. Tetrahedran Lett 41:9075-9078

doi:10.1186/2191-2858-3-7

Cite this article as: Venkateswarlu et al.: Facile and efficient one-pot synthesis of benzimidazoles using lanthanum chloride. Organic and Medicinal Chemistry Letters 2013 3:7.

Submit your manuscript to a SpringerOpen ${ }^{\circ}$ journal and benefit from:

- Convenient online submission

- Rigorous peer review

- Immediate publication on acceptance

- Open access: articles freely available online

- High visibility within the field

- Retaining the copyright to your article

Submit your next manuscript at $\gg$ springeropen.com 